\title{
PKM Peningkatan Kemampuan Membaca dengan Giat Literasi dan Pojok Perpus Di SD Islam Ulil Albab Kecamatan Panarukan
}

\author{
Aenor Rofek ${ }^{1)}$ \\ 1) Universitas Abdurachman Saleh Situbondo \\ gonzalesrofik99@gmail.com
}

\begin{abstract}
ABSTRAK: Kegiatan Literasi dan budaya baca masih tergolong rendah di kabupaten Situbondo, hal ini terlihat dari jumlah kunjungan yang masih sedikit setiap tahunnya di perpustakaan daerah Kabupaten Situbondo dan juga jumlah buku referensi yang dimiliki masih tergolong kurang variatif. Adapun yang terjadi di sekolah mitra yaitu SD Islam Ulil Albab yang memiliki permasalahan kurangnya minat baca sehingga kemampuan membaca siswa masih kurang disebabkan oleh kegiatan literasi yang masih kurang diketahui. Adapun solusi yang ditawarkan yaitu sosialisasi Giat literasi diantaranya meliputi : Membuat kelompok baca, sehingga setiap minggu ada kegiatan membaca dan menulis secara bersama dalam kelompok, Adanya perpustakaan keliling, perpustakaan GO CLAS adalah solusi dimana ada kegiatan dari perpustakaan yang lebih mendekatkan diri pada sisiwa sehingga siswa tidak perlu repot-repot datang ke ruang perpustakaan, Membuat sarana membaca seperti POJOK PERPUS sebagai tempat bacaan bagi siswa.pada prosesnya kegiatan PKM ini meliputi tahap perencanaan dan tindakan. Dengan pelaksanaan kegiatan tersebut dapat diperoleh gambaran bahwa kemampuan literasi anak-anak SD Islam Ulil Albab sudah cukup baik hal ini dapat dilihat dari segi kemampuan anak membaca yang sudah baik, tindak lanjut yang lain adalah komitmen sekolah terhadap kegiatan literasi yang akan dilakukan secara berkesinambungan di sekolah SD Islam Ulil Albab
\end{abstract}

Kata kunci : literasi, pojok perpus, go clas, membaca

\begin{abstract}
Literacy activities and reading culture are still relatively low in Situbondo district, this can be seen from the small number of visits each year in the Situbondo district library and also the number of reference books that are owned are still relatively less varied. As for what happened at the partner school, namely Ulil Albab Islamic Elementary School, which had problems with the lack of reading interest, students' reading skills were still lacking due to literacy activities that were still unknown. The solutions offered are socialization of intensive literacy including: Making reading groups, so that every week there are reading and writing activities together in groups, The existence of mobile libraries, GO CLAS library is a solution where there are activities from the library that are closer to students so students no need to bother coming to the library, making reading facilities like POJOK PERPUS as a place for reading for students. in the process PKM activities include the planning and action stages. With the implementation of this activity, it can be seen that the literacy skills of Ulil Albab Islamic Elementary School children are good enough, this can be seen in terms of the ability of children to read well, another follow up is the school's commitment to literacy activities that will be carried out continuously Islamic Elementary School Ulil Albab.
\end{abstract}

Keywords: literacy, library corner, go clas and read.

\section{PENDAHULUAN}

Kegiatan membaca merupakan kata kunci penting dalam dunia pendidikan, khususnya dalam kegiatan pembelajaran. Siswa SD yang memiliki kemampuan membaca 
yang baik biasanya mencapai hasil yang baik dalam semua mata pelajaran dalam kurikulum. Sebaliknya, siswa SD yang kurang memililki kemampuan membaca, biasanya kurang berhasil di semua mata pelajaran. Dan pada saat ini lagi digalakkan Kegiatan literasi pada awalnya diartikan sebagai keterampilan membaca dan menulis, tetapi pada saat ini pengertiannya mengalami perkembangan. Dalam ranah pembelajaran, kemampuan literasi merupakan kemampuan penting yang harus dimiliki oleh setiap siswa untuk menguasai berbagai mata pelajaran.

Kegiatan Literasi dan budaya baca masih tergolong rendah di kabupaten Situbondo, hal ini terlihat dari jumlah kunjungan yang masih sedikit setiap tahunnya di perpustakaan daerah Kabupaten Situbondo dan juga jumlah buku referensi yang dimiliki masih tergolong kurang variatif.

Literasi sendiri memiliki arti Pengertian literasi secara umum adalah kemampuan individu mengolah dan memahami informasi saat membaca atau menulis. Literasi lebih dari sekedar kemampuan baca tulis, oleh karena itu, literasi tidak terlepas dari ketrampilan bahasa yaitu pengetahuan bahasa tulis dan lisan yang memerlukan serangkaian kemampuan kognitif, pengetahuan tentang genre dan cultural. (www.literasipublik.com/pengertian-literasi.14 Mei 2019).

Pada dasarnya permasalahan minat membaca bagi siswa adalah kurangnya fasilitas dan juga jumlah bacaan yang terbatas, ditambah lagi dengan kurang kreatifnya pengelola perpustakaan dalam mengelola sehingga kurang inovasi dalam menarik pengunjung perpustakaan. Pada tahun 2017 jumlah pengunjung atau yang membaca di perpustakaan sekolah hanya 22 orang saja. Hal ini terjadi di SD Islam Ulil Albab yang memiliki permasalahan kurangnya minat baca sehingga kemampuan membaca siswa masih kurang disebabkan oleh kegiatan literasi yang masih kurang diketahui.

Universitas Abdurachman Saleh Situbondo, dalam hal ini Pusat Penelitian dan Pengabdian Masyarakat (P3M) dan Fakultas Keguruan dan pendidikan, sudah lebih dari satu tahun menjalin kerjasama dengan madrasah atau sekolah negeri sebagai stakholder, salah satunya adalah SD Islam Ulil Albab. Salah satu kerjasama tersebut direalisasikan dalam kegiatan Praktik Pengalaman Lapangan (PPL) dan sebagai sekolah binaan. Berdasarkan data prelimenary research melalui observasi dan wawancara yang dilakukan diketahui beberapa kondisi terkait minat baca, fasilitas pendukung, dan program di SD Islam Ulil Albab yaitu minat baca masih rendah dikarenakan fasiltas dan bahan bacaan terbatas, kegiatan literasi belum dilakukan oleh segenap komponen sekolah dan yang paling penting adalah minat baca siswa yang masih belum ada untuk membaca sebagai kegiatan yang rutin.

Kegiatan PKM ini diharapkan sekolah mampu meningkatkan kegiatan literasi dan budaya membaca siswa sehingga kemampuan membaca semakin baik dan siswa bisa prestasi menjadi meningkat, dengan meningkatnya kemampuan membaca siswa maka dapat menunjang hasil belajar mata pelajaran yang lain.Kegiatan PKM ini dilakukan di SD Islam Ulil Albab sebagai mitra. Kegiatan ini dimaksudkan untuk meningkatkan 
kegiatan literasi siswa di sekolah tersebut agar giat membaca. Kegiatan Literasi di sekolah mitra sangat dibutuhkan dikarenakan masih minimnya kegiatan budaya baca dapat berdampak pada peningkatan prestasi siswa dan juga bisa membuat siswa tidak mau membaca.

Adapun tampak secara visual keadaan sekolah dan perpustakaan yang dimiliki oleh sekolah mitra 1:
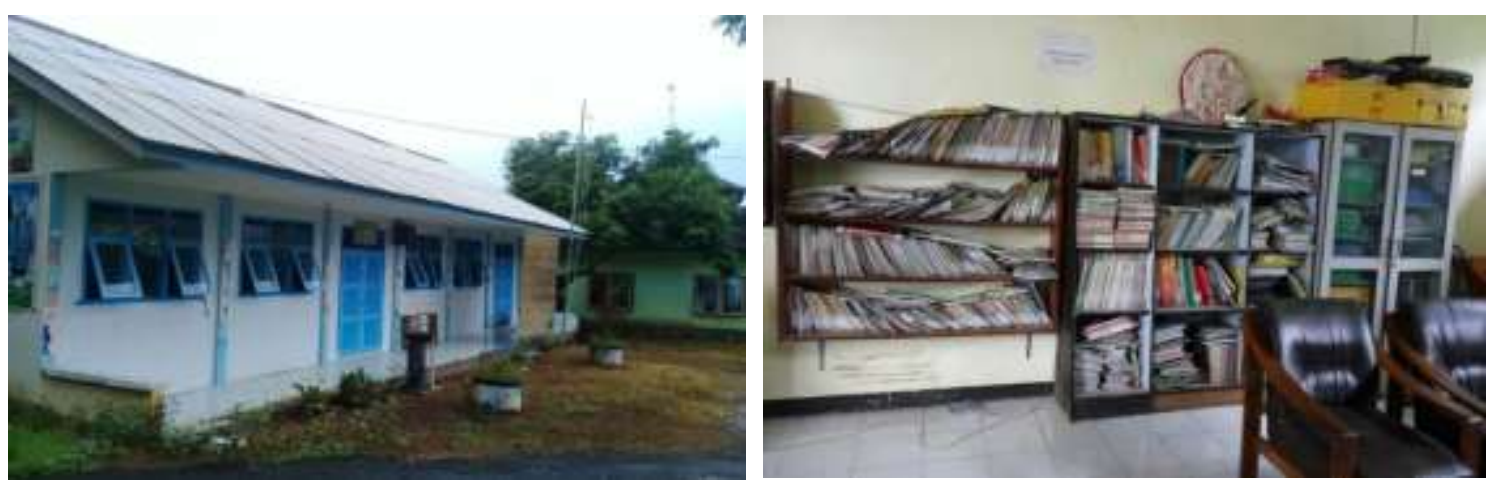

Gambar 1 : foto tampak depan sekolah dan keadaan perpustakaan sekolah.

\section{PERMASALAHAN}

Sebagai mitra dalam pelaksanaan PKM ini adalah SD Islam Ulil Albab. Berdasarkan analisis situasi dapat teridentifikasi beberapa permasalahan yang dihadapai oleh mitra, yaitu:

1. Di sekolah mitra perpustakaan masih sedikit koleksi, Koleksi buku yang kurang beragam, lebih didominasi buku paket pelajaran membuat siswa enggan atau kurang suka membaca.

2. Perpustakaan dan sekolah mitra Belum ada fasilitas tempat baca yang nyaman.

3. Siswa di sekolah mitra lebih suka menonton hiburan, misalnya TV atau video, daripada membaca.

4. Para guru belum melakukan kegiatan yang secara terus menerus, terkadang pembelajaran masih jauh dari penanaman kebiasaan membaca. Sehingga banyak Pembelajaran yang kurang menekankan pada literasi.

\section{METODE PELAKSANAAN}

\section{Mekanisme Pelaksanaan Kegiatan}

Rancangan mekanisme pelaksanaan kegiatan PKM ini dilakukan dengan mengadopsi langkah-langkah action research yang terdiri dari 4 (empat) tahapan, yaitu: perencanaan, tindakan, observasi dan evaluasi, dan refleksi. Kegiatan-kegiatan atau aktivitas-aktivitas dari masing-masing tahapan adalah sebagai berikut.

\section{a. Perencanaan}

Kegiatan-kegiatan yang dilakukan pada tahap perencanaan adalah: 
(1) Rapat bersama Tim P3M dan peneliti/pelaksana.

Tim pelaksana diundang untuk mengadakan pertemuan persiapan pelaksanaan dengan melibatkan P3M Universitas Abdurachman Saleh. Tim pelaksana kemudian diberikan pembekalan mengenai maksud, tujuan, rancangan mekanisme program $\mathrm{P} 3 \mathrm{M}$, dan beberapa hal teknis berkaitan dengan metode/teknik pelaksanaan.

(2) Sosialisasi program PKM pada dua sekolah mitra (khalayak sasaran)

Sosialisasi dilakukan dalam bentuk koordinasi dengan mengundang semua guru, Kepala Sekolah, dan UPTD Dinas Pendidikan Kecamatan Situbondo dan UPTD kecamatan Panarukan yang berkenaan dengan program yang akan dilaksanakan. Kegiatan sosialisasi dilakukan oleh Tim Pelaksana didampingi oleh P3M Universitas Abdurachman Saleh.

\section{(3) Penyusunan program pelatihan}

Berdasarkan hasil identifikasi, hasil analisis permasalahan yang ada, hasil analisis kebutuhan, dan hasil analisis potensi sekolah, selanjutnya disusun program pelatihan.

\section{b. Tindakan}

Tindakan dalam kegiatan ini berupa implementasi Program. Kegiatan-kegiatan yang dilakukan dalam implementasi program adalah (a) pembentukan tim untuk kegiatan Sosialisasi pentingnya Literasi dan budaya baca, (b) melaksanakan pembuatan kelompok baca di setiap kelas (c) Pembuatan sarana Pojok Bacaan sehingga akses untuk membaca tidak hanya terfokus di perpus sehingga, (d) pelaksanaan yang selanjutnya adalah bagaimana membuat kegiatan pojok perpus sehingga siswa lebih dekat dengan perpustakaan sehingga minat membaca akan muncul, e) Penambahan buku bacaan dengan bekerjasama dengan pihak terkait, f) pembentukan KKG khusus bidang mata pelajaran bahasa Indonesia dimana RPP bisa dikaitkan dengan kegiatan literasi.

\section{c. Observasi dan Evaluasi}

Observasi dilakukan terhadap kegiatan literasi di sekolah oleh para guru mitra. Instrumen yang digunakan berupa catatan lapangan. Beberapa hal yang diobservasi adalah kendala-kendala, kekurangan-kekurangan, dan kelemahan-kelemahan yang muncul dalam kegiatan Literasi siswa di SD Islam Ulil Albab. Evaluasi dilakukan terhadap kuantitas dan kualitas produk yang dihasilkan. Produk yang dihasilkan dalam kegiatan ini adalah bentuk pelaksanaan kegiatan yan g dilakukan secara 
bertahap apa sudah dilakukan secara terus menerus atau hanya sebatas kegiatan singkat saja.

\section{d. Refleksi}

Refleksi dilakukan terhadap kegiatan yang telah dilaksanakan. Hal ini dilakukan semata-mata untuk mengetahui kekurangan-kekurangan atau kelebihan-kelebihan terhadap kegiatan-kegiatan yang telah dilakukan dalam rangka untuk menetapkan rekomendasi terhadap keberlangsungan atau pengembangan kegiatan-kegiatan berikutnya.

\section{HASIL DAN PEMBAHASAN}

\section{Hasil}

Kegiatan pengabdian yang berjudul " Peningkatan Kemampuan Membaca Dengan Giat Literasi Dan Pojok Perpus Bagi Siswa SD Islam Ulil Albab “ ini menggunakan Rancangan mekanisme pelaksanaan dengan mengadopsi langkah-langkah action research yang terdiri dari 4 (empat) tahapan, yaitu: perencanaan, tindakan, observasi dan evaluasi, dan refleksi. Kegiatan-kegiatan atau aktivitas-aktivitas dari masing-masing tahapan adalah sebagai berikut.

\section{Tahap Perencanaan}

\section{Rapat bersama Tim P3M dan peneliti/pelaksana.}

Tim pelaksana diundang untuk mengadakan pertemuan persiapan pelaksanaan dengan melibatkan P3M Universitas Abdurachman Saleh. Tim pelaksana kemudian diberikan pembekalan mengenai maksud, tujuan, rancangan mekanisme program P3M, dan beberapa hal teknis berkaitan dengan metode/teknik pelaksanaan.

\section{Sosialisasi program PKM pada sekolah mitra (khalayak sasaran)}

Sosialisasi dilakukan dalam bentuk koordinasi dengan mengundang semua guru, Kepala Sekolah, yang berkenaan dengan program yang akan dilaksanakan. Kegiatan sosialisasi dilakukan oleh Tim Pelaksana didampingi oleh P3M Universitas Abdurachman Saleh di SD Islam Ulil Albab.

\section{Penyusunan program pelatihan}

4. Berdasarkan hasil identifikasi, hasil analisis permasalahan yang ada, hasil analisis kebutuhan, dan hasil analisis potensi sekolah, selanjutnya disusun program pelatihan yang meliputi sosialisasi dan pelaksanaan kegiatan Giat Literasi bagi anak di SD Islam Ulil Albab. 


\section{Tahap Tindakan}

Pada tahap ini pengabdi melaksanankan kegiatan Giat Literasi dan sosialisasi pojok perpus kepada siswa-siswa di SD Islam Ulil Albab. Pada kegiatan yang dilakukan di awal-awal kegiatan yaitu sosilaisasi kepada kepala sekolah, pada kegiatan selanjutnya yaitu kegiatan sosialisasi kepada semua siswa SD Islam Ulil Albab.

Pada kegiatan pertama yang dilakukan dalam pengabdian ini meliputi :

1) Pelaksanaan kegiatan sosialisasi kegiatan :Pada kegiatan ini pengabdi melakukan kegiatan sosialisasi kepada semua siswa-siswi di SD Islam Ulil Albab adapun siswa siswi yang mengikuti kegiatan ini terdiri atas 1 siswa kelas 2, 3 siswa kelas 3, 2 siswa kelas 4, 2 siswa kelas 5 adapun total 8 siswa yang mengikuti pengabdian. Siswa-siswi diberikan pemahaman dan pengertian tentang kegiatan yang akan dilaksanakan oleh pengabdi. Kegiatan ini meliputi sosialisasi tentang Giat Literasi dan pemanfaatan pojok baca atau pojok perpustakaan.
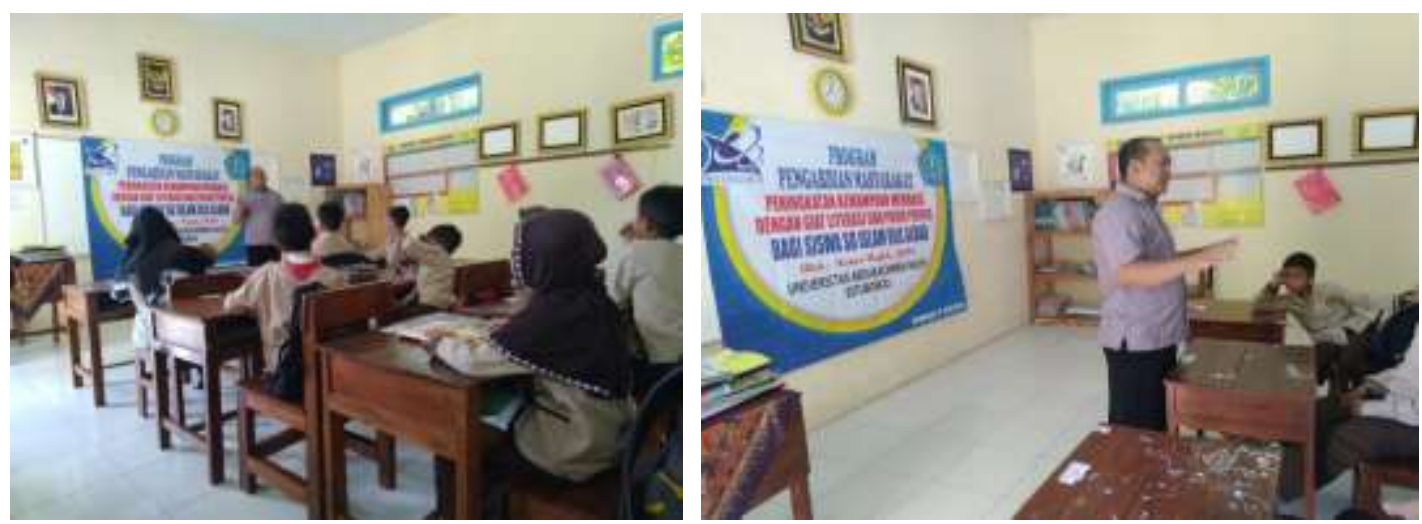

Gambar 2 : kegiatan sosialisasi program PKM Giat Literasi.

2) Pada kegiatan ke dua pengabdian adalah kegiatan pelaksanaan Giat Literasi. Giat literasi adalah kegiatan yang dilakukan dalam rangka menggiatkan kegiatan membaca. Pada kegiatan ini semua siswa diberikan pemahaman serta bagaimana konteks literasi yang sesungguhnya. Pada kegiatan ke dua ini tahapan yang paling penting adalah membiasakan mereka membaca.
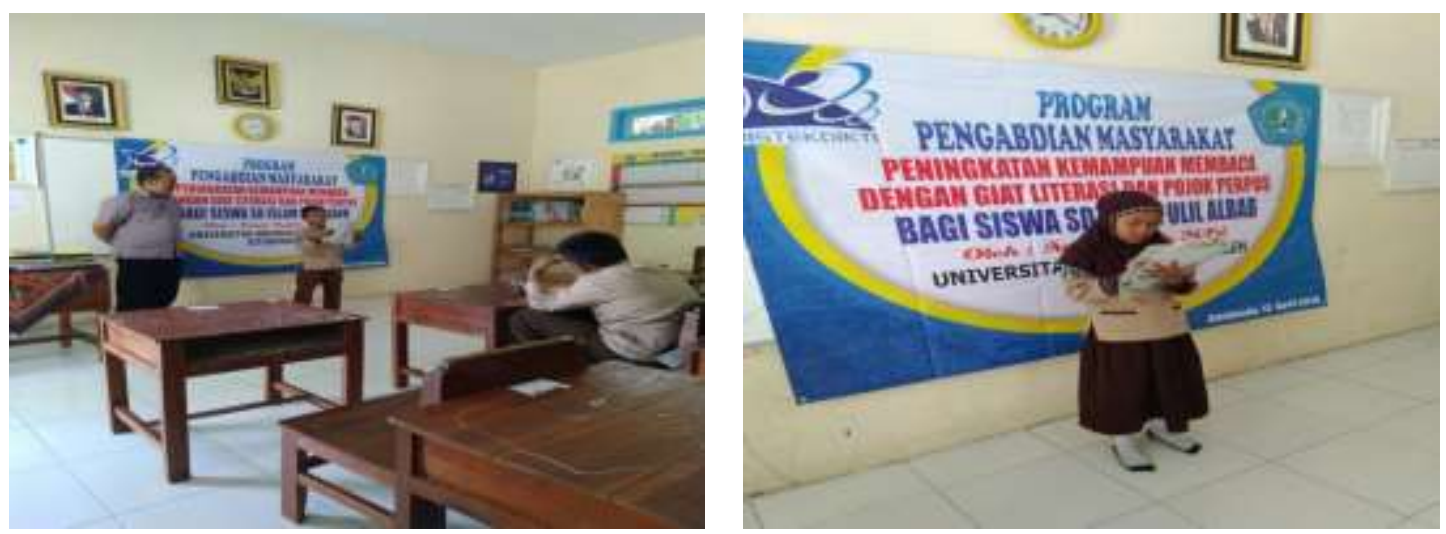

Gambar 3. Pelaksanaan kegiatan Giat Literasi. 
Pada kegiatan diatas siswa-siswi SD Islam Ulil Albab membaca buku yang disediakan di pojok kelas sehingga pembiasaan membaca seperti ini akan melahirkan. Kebiasan membaca akan sangat mempengaruhi kemampuan membaca siswa. Pada foto tersebut siswa yang bernama yudis telah bisa membaca dengan baik dan juga bisa memahami makna dari apa yang dibacanya. Pada analisis tersebut bisa dikatakan bahwa kemampuan literasi dan kemauan untuk membaca sangat terbantu dengan adanya pojok baca yang ada di pojok kelas.
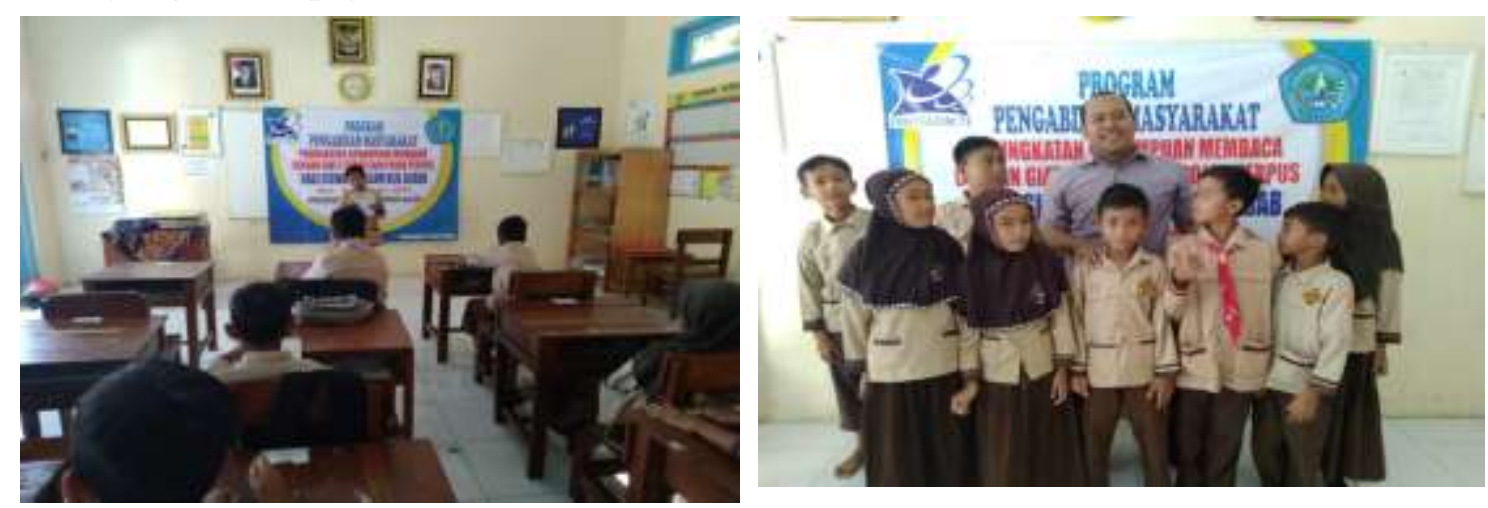

Gambar 4. Pelaksanaan kegiatan Giat Literasi.

Pada pengabdian ini didapatkan hasil yang cukup bagus dimana dari delapan siswa, semua siswa sudah memiliki kemampuan yang baik di bidang membaca. Sehingga giat literasi dan pemanfaatan pojok perpus bisa dikatakan berhasil.

\section{Luaran yang dicapai}

Luaran yang dicapai dalam pengabdian ini meliputi :

1. Siswa-siswi SD Islam Ulil Albab mampu melaksanakan Giat Literasi.

2. Siswa-siswi SD Islam Ulil Albab sudah mau memanfaatkan pojok perpus sebagai sarana membaca bagi peningkatan kemampuan membaca siswa.

3. Guru sudah memiliki skema dan program membaca yang terfokus pada peningkatan kemampuan membaca siswa.

4. Sekolah sudah memberi jadwal membaca bagi siswa setiap hari untuk menggiatkan kegiatan Literasi sekolah.

\section{KESIMPULAN DAN SARAN}

\section{Kesimpulan}

Kegiatan pengabdian Peningkatan Kemampuan Membaca Dengan Giat Literasi Dan Pojok Perpus Bagi Siswa SD Islam Ulil Albab ini telah diperoleh hasil yaitu terdapat peningkatan kemampuan membaca siswa dimana dari 8 siswa yang mengikuti kegiatan Giat literasi ini, mereka telah melaksanakan kegiatan membaca dengan penggunaan pojok 
perpus sebagai sarana dalam membaca. Kegiatan ini difokuskan bagaimana siswa-siswi SD Islam Ulil Albab mampu membaca secara terus-menerus maupun bisa berkesinambungan sehingga giat literasi akan terus berjalan dengan baik di SD Islam Ulil Albab. Adapula kebijakan yang telah dihasilakan dengan adanya kegiatan membaca secara teratur, adanya pojok perpus yang digunakan sebagai sarana membaca siswa-siswi.

\section{Saran}

1. Kegiatan pengabdian ini memerlukan waktu yang cukup lama, akan tetapi pengabdi masih terbentur dana untuk melakukan kegiatan dengan durasi yang lama.

2. Pengabdian Peningkatan Kemampuan Membaca Dengan Giat Literasi Dan Pojok Perpus Bagi Siswa SD Islam Ulil Albab membutuhkan buku penunjang sebagai sarana belajar siswa.

3. Pengabdian ini memerlukan dukungan kebijakan agar kegiatan literasi akan terus ada dan berkembang di sekolah-sekolah.

\section{DAFTAR PUSTAKA}

Faizah, D. U. dkk. (2016). Pedoman Gerakan Literasi Sekolah di Sekolah Dasar. Jakarta: Direktorat Jenderal Pendidikan Dasar dan Menengah Kementerian Pendidikan dan Kebudayaan.

Literasi Publik. 2019. Informasi Literasi. www.literasipublik.com/pengertian-literasi (diakses 14 mei 2019) 